\title{
The Impact of Consumer-Brand Engagement on Smartphone's Brand Loyalty in Indonesia
}

\author{
Ali Wardhana ${ }^{1 *}$, Lilis Susilawaty ${ }^{1}$ \\ ${ }^{1}$ Bunda Mulia University, Jakarta, Indonesia \\ *Corresponding author.Email: awardhana@bundamulia.ac.id
}

\begin{abstract}
Smartphone industry is quite an interesting industry, as a result of the competition that has become intense. The smartphone producer must build customer loyalty to win the market, as they use Consumer-Brand Engagement $(\mathrm{CBE})$ to maintain and strengthen their market shares. The purpose of this research is to examine impact of $\mathrm{CBE}$ on brand loyalty. This research used 5 different brands, which were Vivo, Oppo, Samsung, Xiaomi, and Realme. Data in this research was collected by using questionnaire and then processed by SmartPLS. For the validity test, we used the Average Variance Extracted (AVE), and for reliability test, we used Cronbach's Alpha. After passing both the validity and reliability test, then the hypotheses were tested, and we found that only two dimensions of CBE can used to impact brand loyalty. This brand loyalty will then affect positive WOM and repurchase intention.
\end{abstract}

Keywords: Consumer-Brand Engagement (CBE), Brand Loyalty, Positive WOM, Repurchase Intention

\section{INTRODUCTION}

The smartphone industry these days is quite an interesting industry. A publication conducted by the Pew research center revealed that cellular technology is spreading rapidly throughout the world and it is estimated that more than five billion people are connected via cellular technology, whereas more than half are connected by smartphones [1]. With a large smartphone user population that is expected to continue to grow, it will attract new players to enter the smartphone industry. One of the markets that attracts players in the smartphone industry is Indonesia. Publications from Canalys show that Indonesia is the 4th largest smartphone market in the world, which has quite a lot of potential opportunities, which is evidenced by the fastest market growth of the top-10 market shares in Q3 2019 [2].

A good condition of the Indonesian market is supported by Indonesia's demographics, which is estimated to have an estimated number of young people of 64.19 million, whereas 88.66 percent of these youth have cell phones [3]. This youth group plays an important role, because smartphone adoption is growing faster among the younger generations in developing countries and it is sure in some countries that those under 35 are more likely to own a smartphone than those aged 50 years and over [1]. In addition, people under 35 are of the productive age who have the affordability to buy a smartphone. Seeing the attractive Indonesian smartphone market and potential consumers, it will open up opportunities for new players to compete in Indonesia. For example, in July 2018, Realme entered the Indonesian market right after two months of Realme officially being founded in May 2018, whereas the company has a mission of more young people whose lives are made easier with the technology provided.

This can be a clear evidence that the young generation in Indonesia is a potential target market. In the future, it is not impossible that new players will emerge in the Indonesian smartphone industry. Therefore, these players must be able to retain consumers by creating those who are loyal to the product brand and continue to buy products with the same brand. Consumer loyalty can be built with brands, when brands are not only focused on products, but also on their customers by creating strong relationships with their consumers through consumer participation and interaction. The active interaction between the customer and the company, whether transactional or non-transactional in nature, is defined as consumer engagement that can create long-lasting, deeper, more meaningful relationships between the company and customers, and is believed to have an impact on future growth [4]. By using the same concept and changing company objects into more specific objects, such as brands, Consumer-Brand Engagement (CBE) will be obtained. There are 2 previous studies which show that the concept of CBE affects brand loyalty [5] [6]. Through brand loyalty, loyal consumers will be created, make repeat purchases, recommend brands to their surroundings, and tend to pay high prices [7]. Previous research in Indonesia on a smartphone brand, namely Oppo, has proven that brand loyalty has an impact on positive word of mouth and repurchase intention [8]. Referring to the ability of brands that are considered capable of being a vehicle to meet the challenges of building long-term relationships with customers [9], the relationship with these customers can become a strength for smartphone industry players in the midst of increasingly-fierce competition. 
Therefore, this research examined the impact of CBE on brand loyalty, and in the end, it will have an impact on positive word of mouth and repurchase intention among five brands that rule the market in Indonesia according to International Data Corporation (IDC), namely Vivo, Oppo, Samsung, Xiaomi, and Realme.

\section{LITERATURE REVIEW}

\subsection{Consumer-Brand Engagement (CBE)}

CBE is one example of consumer-brand relationship paradigm that serves to capture behavior customer with brand. $\mathrm{CBE}$ is based on consumer engagement that uses brand power. This term of engagement uses the concept of organizational psychology, whereas engagement is holistic in order to capture three facets of individual engagement in one framework, namely cognitive (absorption), emotional (dedication) and behavior (vigor) aspects [10]. By combining the engagement definition and brand, then $\mathrm{CBE}$ can be defined as a positive state-of-mind from customer associated with brand use, causing somebody to feel satisfied and have three characteristics (vigor, dedication and absorption). [10]. The definition from previous research focused on customer's state-of-mind. On the other hand, Fernandes and Moreira's research focused on their activity saying that $\mathrm{CBE}$ is a better predictor of loyalty-related outcomes, because CBE is a brand-related activity that deals with cognition, emotion, and consumer behaviour. [6]. Previous research shows that CBE impacts brand loyalty [5] [6].

$\mathrm{H}_{1}$ : Consumer-Brand Engagement (CBE) with three dimensions, namely cognitive, affective, and behavioural aspects, has an impact on Brand Loyalty.

\subsection{Brand Loyalty}

In a fast-growing industry and strong competition such as the smartphone industry, building loyal customer of a brand becomes a must, as a method to protect the market share, because through that loyalty, it can create repeat purchase [7]. The loyalty of consumer to brand is called brand loyalty. Therefore, brand loyalty can be defined as a deeply commitment to re-buy a product with the same brand consistently in the future [11]. Brand loyalty have four phases: cognitive, affective, conative, and action [11] and two dimensions: attitudinal and behavioural brand loyalty [12].

Brand loyalty has some impacts on the company such as repeat repurchase that comes from behavior loyalty and consumer recommendations for certain products that come from attitudinal brand loyalty [13]. This consumer recommendation is called Word-of-Mouth (WOM) and it has a strong impact on purchase [14]. Previous research shows that there are two categories of WOM, which are Positive Word-of-Mouth (PWOM) and Negative Word-ofMouth (NWOM). PWOM can make consumers shift their purchase and attract their attention [14].
$\mathrm{H}_{2}$ : Brand Loyalty impacts positive WOM.

$\mathrm{H}_{3}$ : Brand Loyalty impacts Repurchase Intention.

\section{METHODOLOGY}

The number of samples in this research is 118 respondents and they consist of 46 males and 72 females. According to previous research, this research categorized the ages of respondent into two groups [1]. Between 18 to 34 years old, there are 111 respondents and the remaining 7 respondents aged over 35 years old. With the majority respondent ages in between 18 to 34 years old, it can be said that in this research the respondents were young. This research found that almost a half of the respondents used Samsung brand (49\%) and only 3\% use Realme brand. Questionnaires in this research uses 5 -item Likert scale by following the scale pattern: 1 = strongly disagree, $2=$ disagree, $3=$ neutral, $4=$ agree and $5=$ strongly agree [15].

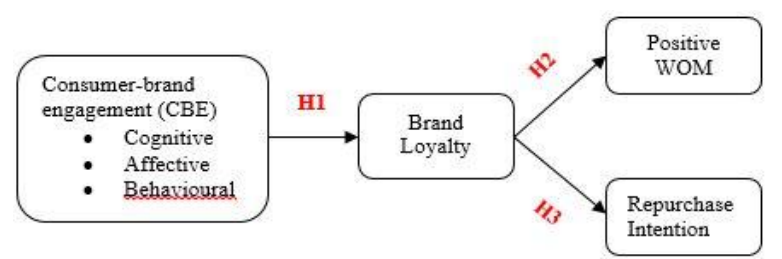

Figure 1 Theoretical Framework

\section{DATA ANALYSIS}

This research used the loading-factor value as a convergent validity test, whereas the value must be more than 0.7 . Unfortunately, one dimension of CBE - cognitive - does not pass the test. After eliminating the cognitive dimension, this research continued the validity test with a new framework, and the result becomes much better.

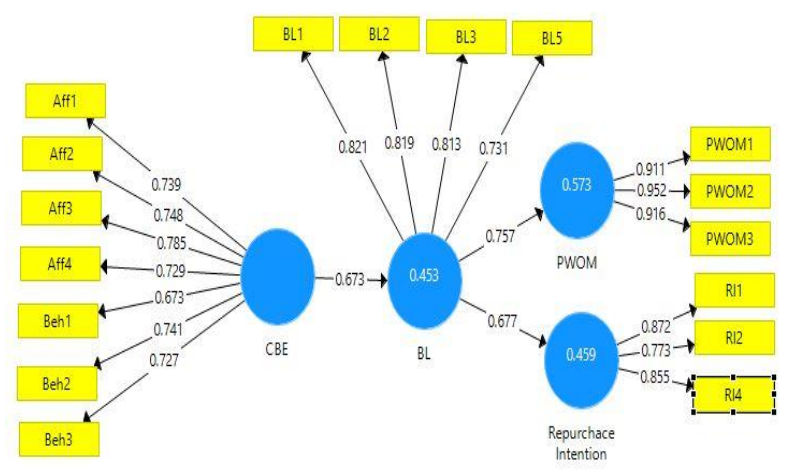

Figure 2 Loading-factor result

Besides using the loading factor as a convergent validity test, this research also used the Average Variance Extracted (AVE), whereas the AVE value is expected to be higher than 0.5 , because this value indicates that the instrument used to measure the concept has a high correlation [15]. 
Table 1 Validity Test using AVE

\begin{tabular}{cc} 
& AVE \\
\hline Brand Loyalty & 0.635 \\
\hline CBE & 0.540 \\
\hline Positive WOM & 0.858 \\
\hline Repurchase Intention & 0.696 \\
\hline
\end{tabular}

After all item has passed the validity test, then they have to pass the reliability test. This reliability test uses Cronbach's Alpha, whereas the measured item can be accepted, if the Cronbach's Alpha value is in the range between 0.6 and 0.7 [15] and the composite reliability is expected to be above $0.7[16]$.

Table 2 Reliability Test using CA and CR

\begin{tabular}{lcc} 
& CA & CR \\
\hline Brand Loyalty & 0.808 & 0.874 \\
\hline CBE & 0.858 & 0.892 \\
\hline Positive WOM & 0.918 & 0.948 \\
\hline Repurchase Intention & 0.784 & 0.873 \\
\hline
\end{tabular}

After passing the validity and reliability test, the next step is conducting the hypothesis tests.

$\mathrm{H}_{1}$ : Consumer-brand engagement (CBE) with three dimensions, namely cognitive, affective and behavioural aspects, has an impact on Brand Loyalty.

In this hypothesis test, it shows that CBE has a significant and positive impact on brand loyalty, which appears at a pvalue below 0.05 .

\section{H2: Brand Loyalty impacts Positive WOM.}

In this hypothesis test, it shows that brand loyalty has a significant and positive impact on Positive WOM, which appears at a p-value below 0.05 .

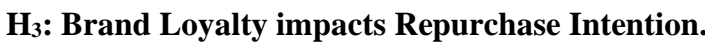
In this hypothesis test, it shows that brand loyalty has a significant and positive impact on repurchase intention, which appears at a p-value below 0.05 .

\begin{tabular}{|c|c|c|c|}
\hline Hypothesis & $\begin{array}{c}\text { Path } \\
\text { Coefficient }\end{array}$ & $\begin{array}{c}\text { t- } \\
\text { Value }\end{array}$ & Result \\
\hline $\begin{array}{l}\mathrm{H}_{1} \text { : Consumer- } \\
\text { Brand } \\
\text { Engagement } \\
\text { (CBE) impacts } \\
\text { Brand Loyalty }\end{array}$ & 0.000 & 11.652 & Supported \\
\hline $\begin{array}{l}\mathrm{H}_{2} \text { : Brand Loyalty } \\
\text { impacts Positive } \\
\text { WOM }\end{array}$ & 0.000 & 19.329 & Supported \\
\hline
\end{tabular}

\begin{tabular}{llll}
$\mathrm{H}_{3}$ : Brand Loyalty & & & \\
impacts & 0.000 & 11.231 & Supported \\
$\begin{array}{l}\text { Repurchase } \\
\text { Intention }\end{array}$ & & & \\
\hline
\end{tabular}

Through this research, it can be seen that CBE can affect brand loyalty in smartphone industry as well as creating positive WOM and repurchase intention. Unfortunately from three dimension from CBE only two dimension that supported to build CBE, namely affective, and behavioural aspects while cognitive aspects not supported.

\section{CONCLUSIONS AND DISCUSSIONS}

From this research there are three conclusions that can be drawn. First with build a good relationship by CBE smartphone manufacter can increase repurchase intention and positive wom at the same time. This result is similar with presious study [19]. In other words the relationship between customer and brand becomes important in order to built brand loyalty and at the end that loyalty can help smartphone manufacturer to win the market. Brand is no longer just a name for product, but becomes a critical tool to build the relationship. Second, from there dimension only two dimension that supported CBE, namely affective, and behavioural aspects. This finding quite interesting because even with only two dimensions CBE can still have an effect on brand loyalty. This intresting findings have two meaning. First two dimension, namely affective, and behavioural aspects have becomes clear evidence and more supportive, that brand becomes a critical tool that plays in the aspect customers' emotion, because affective dimension talks about this emotional aspect.

This result is similar with previous study that the emotional aspect can affect brand loyalty that manifest in positive wom and repurchase intention [17]. Second meaning is cognitive aspect cannot be used to build CBE in smartphone brand because the brands used in this research are not luxurious brands, and smartphone has become a daily need. Moreover, 5 smartphone brands offer similar features and attributes resulting consumer not attention detail. This result can become future interesting research by comparing the CBE impact between the luxurious and non-luxurious brands. Finally, from this reseach, five brands that rule the market in Indonesia can enlarges their market share with positive wom and repurchase intention by build relationship with their consumer by focus to affective, and behavioural aspects.

\section{REFERENCES}

[1] Taylor, K., Silver, L, Smartphone Ownership Is Growing Rapidly Around the World, but Not Always Equally. 2019.https://www.pewresearch.org/global/ 2019/02/05/smartphone-ownership-is-growingrapidlyaround-the-world-but-not-always-equally. 
[2] Canalys, Canalys: Indonesia grew fastest in global top 10 markets and reached a record 11.5 million smartphone shipments in Q3 2019, 2019. https://www.canalys.com/newsroom/indonesiasmartphone-market-q3-2019

[3] Central Statistics Agency (BPS). Youth Statistics 2019, Central Statistics Agency (BPS), Indonesia, 2019, pp 196

[4] Kumar, V., Aksoy, L., Donkers, B., Venkatesan, R., Wiesel, T., Tillmanns, S. Undervalued or overvalued customers: capturing total customer engagement value. Journal of service research, 2010. 13(3), 297-310.

[5] Rather, R. A., Tehseen, S., Parrey, S. H. Promoting customer brand engagement and brand loyalty through customer brand identification and value congruity. Spanish Journal of Marketing-ESIC, 2018

[6] Fernandes, T., Moreira, M, Consumer brand engagement, satisfaction and brand loyalty: a comparative study between functional and emotional brand relationships. Journal of Product \& Brand Management. 2019.

[7] Erciş, A., Ünal, S., Candan, F. B., Yıldırım, H, The effect of brand satisfaction, trust and brand commitment on loyalty and repurchase intentions, Procedia-Social and Behavioral Sciences, 2012, 58, 1395-1404

[8] Wardhana, A., Yulia, Y. Pengaruh kemudahan penggunaan, nilai tidak tergantikan, kualitas sistem, kesadaran teknologi dan desain visual terhadap positif word of mouth dan niat pembelian ulang dengan mediasi loyalitas merek. Managament Insight: Jurnal Ilmiah Manajemen, 2020, 15(1), 65-77.

[9] Pedeliento, G., Andreini, D., Bergamaschi, M., Salo, $\mathrm{J}$, Brand and product attachment in an industrial context: The effects on brand loyalty. Industrial Marketing Management, 2016, 53, 194-206.

[10] Dwivedi, A, A higher-order model of consumer brand engagement and its impact on loyalty intentions. Journal of Retailing and Consumer Services, 2015, 24, 100-109.

[11] Oliver, R. L, Whence consumer loyalty? Journal of Marketing, 1999. 63, 33.

[12] Giovanis, A., Athanasopoulou, P, Gen Y-ers' brand loyalty drivers in emerging devices. Marketing Intelligence \& Planning, 2017

[13] Hsu, C. L., Chen, Y. C., Yang, T. N., Lin, W. K., Liu, Y. H, Does product design matter? Exploring its influences in consumers' psychological responses and brand loyalty, Information Technology \& People, 2018

[14] East, R., Romaniuk, J., Chawdhary, R., Uncles, M, The impact of word of mouth on intention to purchase currently used and other brands. International Journal of Market Research, 2017, 59(3), 321-334.

[15] Sekaran, U., Bougie, R.J, Research Methods for Business: A Skill Building Approach. United Kingdom: John Wiley and Sons Ltd, 2016

[16] Ghozali, I., Latan, Partial Least Squares, Konsep, Teknik dan aplikasi menggunakan program SmartPLS 3.0. Badan Penerbit - Undip, 2015

[17] Wardhana, A., Tera, S. S. Pengaruh brand passion, brand commitment dan brand intimacy terhadap repurchase intention, positive WOM dan pay price premium, Business Management Journal, 2020, 16(1), 7.

[18] Giovanis A, Athanasopoulou P, Understanding lovemark brands: Dimensions and effect on Brand loyalty in high-technology products, Spanish Journal of Marketing - ESIC, 2018, Vol. 22 Issue: 3, pp.272-294

[19] Wardhana, A, Yulia. Pengaruh kemudahan penggunaan, nilai tidak tergantikan, kualitas sistem, kesadaran teknologi dan desain visual terhadap positif word of mouth dan niat pembelian ulang dengan mediasi loyalitas merek. Managament Insight: Jurnal Ilmiah Manajemen 15.1 (2020): 65-77. 